\title{
Authentic-interactive activities to promote oral production on a virtual platform
}

\section{Actividades interactivas-auténticas para promover la producción oral en una plataforma virtual}

\author{
FLORES-GONZÁLEZ, Norma†* \\ Benemérita Universidad Autónoma de Puebla, Faculty of Languages, Mexico.
}

ID $1^{\text {st }}$ Author: Norma, Flores-González / ORC ID: 0000-0002-4967-8854, Researcher ID Thomson: S-6917-2018, CVU CONACYT ID: 957036

DOI: $10.35429 /$ JCA.2020.15.4.26.35

Received July 25, 2020; Accepted December 30, 2020

\begin{abstract}
Implementing learning or communicative strategies are not enough to develop oral production when learning English as a Foreign language; indeed, it is necessary to provide authentic activities that engage students in the act of speaking. The objective of this research is to know if the interactive activities operated in the Moodle platform promote oral production and identify the possible association between their scores from the instructional design and their speaking level from a standardized exam. For this, a longitudinal quantitative approach was carried out during spring 2020 in the Teaching English Bachelor at BUAP, having a sample of 20 subjects. The results demonstrated that the use of authentic-interactive activities improved the students' speaking competence significantly. Furthermore, this study pretends to contribute with useful theoretical information for teachers and students who want to select appropriate tasks to improve this competence. It is essential to clarify that this is an innovative study since it promotes the use of activities and strategies mediated by technology asynchronously and synchronously, which are flexible and suitable for students' needs in times of contingence.
\end{abstract}

Authentic-interactive activities, Oral production, Virtual environment

\begin{abstract}
Resumen
Implementar estrategias de aprendizaje o comunicativas no es suficiente para desarrollar la producción oral al aprender inglés como lengua extranjera; de hecho, es necesario aplicar actividades auténticas que involucren a los estudiantes en el acto de hablar. El objetivo de esta investigación es conocer si las actividades interactivas operables en la plataforma Moodle promueven la producción oral e identificar la posible asociación entre sus calificaciones del diseño instruccional y su nivel de habla de un examen estandarizado. Para ello, se realizó un estudio cuantitativo longitudinal durante la primavera de 2020 en la Licenciatura de la Enseñanza del Inglés de la BUAP, teniendo una muestra de 20 sujetos. Los resultados demostraron que el uso de actividades interactivas auténticas mejoró significativamente la competencia oral de los estudiantes. Además, este estudio pretende aportar información teórica útil para profesores y estudiantes que quieran seleccionar tareas adecuadas para mejorar esta competencia. Es fundamental aclarar que se trata de un estudio innovador ya que promueve el uso de actividades y estrategias mediadas por tecnología de forma asincrónica y sincrónica, que son flexibles y adecuadas a las necesidades de los estudiantes en tiempos de contingencia.
\end{abstract}

Actividades auténticas-interactivas, Producción oral, Entorno virtual

Citation: FLORES-GONZÁLEZ, Norma. Authentic-interactive activities to promote oral production on a virtual platform. Journal of Applied Computing. 2020. 4-15:26-35.

\footnotetext{
* Correspondence to the Author (Email: norma-fg@hotmail.com)

$\dagger$ Researcher contributing as first author.
} 


\section{Introduction}

The necessity of learning English as a foreign language is increasing in the Mexican educational field, especially in the academic one. In that attempt, students are supposed to learn how to write, listen, read, and speak it to use the language as a way to convey messages. However, the last skill represents an obstacle for the majority of learners who struggle with different vicissitudes such as pronounce isolated words, phrases, or disconnected sentences getting poor oral production, and they attribute it to their lack of communication and learning strategies, vocabulary, and practice. That is why the present research is important because it could offer some alternatives to avoid those obstacles. At this point, there are many studies in the state of the art that propose different means to improve oral production, which include learning and communication strategies, techniques, approaches, methods, or activities that promote that production, among others in on-site spaces. Nonetheless, what could teachers do when the development of such a skill has to be outside the classroom, in a non-native context, and under virtual learning due to current circumstances?

Taking into account the situation described above, the objective of this study is to know if an instructional design with interactive activities operated in the Moodle platform promotes oral production and identify the possible association between subjects' scores from that instructional design and their speaking level from a standardized test. For accomplishing it, two research questions will guide the research: Do authentic-interactive activities from the instructional design promote subjects' oral production?

Is there a possible association between the subjects' scores from the instructional design and their oral production level from a standardized exam?

Now, it is essential to define some key concepts to frame the research theoretically.

\section{Literature review}

Over the years, speaking has been considered a difficult skill to instill in students, mainly because of the lack of situations where they recognize its essential function like in meaningful tasks, real and immediate context for social interactions. As Bygate (1987, p. 1) mentions, "our learners often need to be able to speak with confidence in order to carry out many of their most basic transactions. It is the skill by which they are most frequently judge, and through which they make or lose friends".

\section{Oral production}

For effective communication between learners, it is crucial to provide them with the necessary accurate vocabulary, grammatical structures, and in general, suitable input.

Besides, when students are in the process of learning a foreign language, they need to have activities where communicative competence takes place; otherwise, they will never develop their speaking skills.

Communicative competence is a multifaceted concept, which regarding Savignon, as cited in Gónzalez (2008, p. 8), "depends on the negotiation of meaning". Then, its success is directly related to the speakers' cooperation and interests. That is why it is not simple; it implies more than generating utterances in isolation without counting on a context, social rules, or speakers' background. On the contrary, those speeches must convey accurate sense and meaning so that the receptor could comprehend the intended messages (Méndez, 2017).

Moreover, there is a big difference between speaking and oral skills. The former are students' drills according to pre-fixed conversation models, and the latter is a process where both listening and speaking must interact themselves to have successful communication between the speaker and receptor by alternating their roles respecting social and interactional rules. 
In speaking, there are two processes. According to Saville-Troike, the top-down looks for the handling of the topic as well as cultural knowledge. On the contrary, "The language knowledge involved in bottom-up processes for speech production includes appropriate vocabulary, features of pronunciation, grammatical patterns..." (2012, p. 175).

\section{Strategies to develop oral production}

In the educational field, the term strategy seems to have two connotations. The first refers to the means used to achieve meta-cognition in language learning; that is, learn and evaluate the process, often called learning strategy (LS). The second is associated with its use in a conversation to fix the communication, called communication strategy (CS). For that reason, different studies state the significance of teaching both to foster oral production.

On the one hand, for Chamot (2004, p. 1), language learning strategies are "the conscious thoughts and actions that learners take in order to achieve a learning goal". Besides, for Weinstein, Husman \& Dierking (2000: 727), "learning strategies include any thoughts, behaviours, beliefs or emotions that facilitate the acquisition, understanding or later transfer of new knowledge and skills".

On the other hand, communication strategies are directly related to oral communication, and one of the first researchers to identify them was Varadi in the 70s.

Taking into account Bialystok (1990: 138), a CS is "the dynamic interaction of the components of language processing that balance each other in their level of involvement to meet tasks demands".

Different authors have researched learning strategies as Takeuchi, 1993; Green \& Oxford, 1995; Cohen, 1998; Chamot et al., 1999 or communication strategies like Tarone, 1977; Bialystok, 1990; Poulisse, 1993; Yule \& Tarone, 1990; Saville-Troike, 2012, Flores-González et al., 2019).
However, the use of strategies does not ensure the development of oral competence in students, and some studies (Grenfell \& Harris, 1999; Macaro, 2006; Tragant \& Victori, 2006) point out that. Besides, Vann and Abraham (1990) figured out in a study that both high and low proficient learners used a variety of learning strategies in their learning process, but the key difference was how they used them with the activities.

\section{Authentic activities}

Strategies by itself do not promote oral production; indeed, original activities are essential to engage learners in meaningful communicative exchanges. However, activities will be considered as authentic only if they face students in real situations where natural and spontaneous performances in formal and informal social contexts take place. In this way, these type of activities could overcome learners' feelings regarding academic tasks, which according to their perceptions, they are not focused on daily life. They seem to be for different contexts that are demotivating as they do not identify the usefulness of what they learn. Therefore, that learning is not very significant due to its limitations: use only in classrooms and lack of a link between their previous and new knowledge.

Some of the most outstanding characteristics of authentic activities are:

\begin{tabular}{|l|l|}
\hline \multicolumn{1}{|c|}{ Features } & \multicolumn{1}{c|}{ Authors } \\
\hline $\begin{array}{l}\text { They engage students in } \\
\text { collaborative work. }\end{array}$ & (Gordon, 1998) \\
\hline $\begin{array}{l}\text { Authentic activities in } \\
\text { meaningful and real situations. }\end{array}$ & $\begin{array}{l}\text { (Lebow \& Wager, } \\
\text { González, et al., } \\
\text { Flores- }\end{array}$ \\
\hline $\begin{array}{l}\text { Authentic activities focus on } \\
\text { the task from diverse } \\
\text { viewpoints through an } \\
\text { assortment of resources. }\end{array}$ & $\begin{array}{l}\text { (Sternberg et al., } \\
\text { Vye et al., 1990) }\end{array}$ \\
\hline $\begin{array}{l}\text { They foster critical and } \\
\text { reflective thinking. }\end{array}$ & (Young, 1993) \\
\hline $\begin{array}{l}\text { The design of the activity, as } \\
\text { well as its objectives, match } \\
\text { with the evaluation process. }\end{array}$ & \begin{tabular}{l} 
(Herrington \& \\
\hline $\begin{array}{l}\text { As they are integrative } \\
\text { activities, investigative skills } \\
\text { and time are required to carry } \\
\text { them out. 1998) }\end{array}$
\end{tabular} \\
\hline
\end{tabular}

Tabla 1 Features of an authentic task

FLORES-GONZÁLEZ, Norma. Authentic-interactive activities to promote oral production on a virtual platform. Journal of Applied Computing. 2020 
Furthermore, if such authentic activities are implemented in a virtual system, key elements are required for its proper functioning and purpose. They deal with the teacher's role to design, implement, and monitor the instructional design and students' roles to work individually and collaboratively in it.

\section{Interactivite activies}

Interaction is the scenario where students show what they know of a language (grammar, vocabulary, linguistic competence, and performance) and improve their oral production. Thus, said scenario must be a motivating, trustworthy, and friendly atmosphere for the students, without causing fear to speak and interacting with another as well as providing authentic-interactive activities that hook them in communicative purposes with effective language learning in and outside classrooms.

At this point, task-based learning allows developing communicative tasks to interact in real situations collaboratively, which fosters practicing, developing discursive strategies, and critically providing feedback to the rest of the speakers.

Besides, those types of tasks have specific aims like obtaining information, discussions about interesting topics, and learning about the culture, which according to Moss and Ross-Feldman (2003), provide meaningful insight in an active-learning context. All in all, such activities depend on the creativity of the teachers. However, citing Csikszentmihalyi (2013), some aspects are needed for that objective like

Preparation: Arousing curiosity of a problematic situation.

Incubation: Ideas fly below the threshold of consciousness.

Insight: The moment when the puzzle starts to fall together.

Evaluation: Deciding if the insight is valuable and worth pursuing.

Elaboration: Translating the insight into its final work (p. 79).

The success or failure of these types of activities depends on the level of interaction in such virtual environments and the interactive technology that mediates the learning process. In this case, such technology consists of any tool or medium that helps students interact with their peers or with online materials.
Taking into account the pandemic and confinement that humanity is facing now, education has evolved from traditional to virtual classrooms, which is causing problems to students ad teachers due to their lack of strategies and ways to implement it. Thus, the following lines describe synchronous and asynchronous activities as insight for their inclusion in virtual environments.

Synchronous activities. These types of activities take place in real-time; then, the speaker and listener must be present and interact by video or audio conferencing with the help of some digital tools or applications.

Some advantages of asynchronous activities are the overcome of the learning isolation process and live teaching sessions.

Asynchronous activities. They are timeindependent activities that promote learning at the students' own pace according to their needs, times, and objectives. This interaction occurs by using asynchronous tools such as the discussion forums, e-mails, and some applications that allow them to record and host said participation on a platform or virtual space, so their audience listens to it at any time.

Students who work on this modality should be motivated and have clear objectives since they do activities on their own with online explanations provided by the online course and their autonomous learning.

Some examples of synchronous activities are life-classes with a pre-determined objective, video recording to have discussions or debates, as well as platforms for meetings, questionanswer sessions, and others. Asynchronous examples are quizzes, pre-recorded videos, integrated tasks, extra exercises with feedback through forums, or practice through blogs and wikis. 
Ideally, virtual courses should be balanced and include both types of activities; in that way, teachers and students take advantage of the benefits of each one. On the one hand, learners work at their own pace in a flexible environment regarding time and space, have immediate help from their facilitator, work individually and collaboratively with authenticinteractive activities developing their listening, reading, writing, and speaking skills autonomously to some extend. On the other hand, teachers offer students active and innovative learning by using different delivered formats as well as learning methods, which could fit learning styles suitably.

\section{Methodology}

Different studies have focussed on the use of technology for teaching and learning process with a variety of methodologies and scopes such Flores-González's research (2019), which proposed the use of blended-learning modality to promote extensive reading; Felix's study (2001) that presents perspectives on the Web as a medium of language instruction or Ushida (2005) who searches about motivation and attitudes towards an online language course context. Besides, Sagarra and Zapata (2008) state significant learning when combining instructional courses with CALL, or Wang and Wang (2010), who point out positive students' perception in a CALL course implementation. Finally, Flores-González, and FernandezCrispín (2019), whose study shows how strategies mediated by technology promote meaningful learning.

For the present research, a longitudinal quantitative approach was carried out during spring 2020 in the Teaching English Bachelor at Benemérita Universidad Autónoma de Puebla. The selection of this methodology was due to its advantages regarding measuring (Leedy \& Ormrod, 2013) the same phenomenon in different times repeatedly by using the same method that in this case was done by measuring subjects' speaking level with checklists and rubrics during the instructional design to analyze quantitative data and changes during four months. Then, those results were compared with the speaking scores gotten from a standardized test. Besides, it also allows the researcher to describe the situation (Cresswell, 2005) and identify possible relationships between variables.

\section{Sample.}

It was randomly selected and composed of 20 subjects who shared common characteristics like: have synchronous sessions 4 hours a week and work independently on the platform at least 10 hours a week. All of them accredited B1 and B1+ in speaking.

The data gathered from the subjects' scores of the instructional design, which lasted four months, were analyzed according to the model of analysis below.

\begin{tabular}{|c|c|c|}
\hline $\begin{array}{l}\text { Research } \\
\text { question } 1\end{array}$ & \multicolumn{2}{|c|}{ Indicator } \\
\hline $\begin{array}{l}\text { Do authentic- } \\
\text { interactive } \\
\text { activities from } \\
\text { the instructional } \\
\text { design promote } \\
\text { subjects, oral } \\
\text { production? }\end{array}$ & \multicolumn{2}{|c|}{$\begin{array}{l}\text { Grades got from the instructional } \\
\text { design taking into account } \\
\text { synchronous and asynchronous } \\
\text { authentic-interactive activities in } \\
\text { the Moodle platform, which were } \\
\text { graded based on rubrics and } \\
\text { checklists. }\end{array}$} \\
\hline $\begin{array}{c}\text { Research } \\
\text { question } 2\end{array}$ & \multicolumn{2}{|c|}{ Variables } \\
\hline $\begin{array}{l}\text { Is there a possible } \\
\text { association } \\
\text { between the } \\
\text { subjects' scores } \\
\text { from the } \\
\text { instructional } \\
\text { design and their } \\
\text { oral production } \\
\text { level from a } \\
\text { standardized } \\
\text { exam? }\end{array}$ & $\begin{array}{l}\text { Variable } 1 \\
\text { General } \\
\text { subjects scores } \\
\text { from the } \\
\text { instructional } \\
\text { design based on } \\
\text { authentic- } \\
\text { interactive } \\
\text { activities }\end{array}$ & $\begin{array}{l}\text { Variable } 2 \\
\text { Subjects' } \\
\text { scores from a } \\
\text { standardized } \\
\text { exam }\end{array}$ \\
\hline
\end{tabular}

Table 2 Model of analysis

\section{Results}

RQ1. Do authentic-interactive activities from the instructional design promote subjects' oral production?

The instructional design followed the ADDIE model for e-learning, whose acronym stands for analysis, design, development, implementation, and evaluation that are its five stages.

Regarding the content of the course, it comprises both synchronous and asynchronous authentic-interactive activities according to competencies and descriptors to reach a B2 level in speaking, as shown in the following tables. 
Synchronous authentic-interactive activities

\begin{tabular}{|l|l|}
$\begin{array}{l}\text { Before the speech activity } \\
\text { (engagement into the } \\
\text { topic) }\end{array}$ & $\begin{array}{l}\text { Rank ideas and } \\
\text { brainstorming }\end{array}$ \\
\hline $\begin{array}{l}\text { During the speech } \\
\text { activity }\end{array}$ & \begin{tabular}{l} 
Activities based on role- \\
plays and songs \\
\cline { 2 - 2 } Immersive environments \\
according to a pre-fixed \\
topic
\end{tabular} \\
\hline After the speech activity & Summarizing \\
\cline { 2 - 2 } & Question-answer set \\
\hline
\end{tabular}

Table 3 Synchronous authentic-interactive activities

\begin{tabular}{|c|l|}
\hline \multicolumn{2}{|c|}{ Asynchronous authentic-interactive activities } \\
\hline 1. & Argumenting by using Voxopop \\
\hline 2. & $\begin{array}{l}\text { Explaining points of view in a debate by sing } \\
\text { Screencast-o-matic }\end{array}$ \\
\hline 3. & $\begin{array}{l}\text { Predicting consequences, causes, or hypothetical } \\
\text { situations with Voicethread }\end{array}$ \\
\hline 4. & Defending points of view with Atto \\
\hline
\end{tabular}

Table 4 Asynchronous authentic-interactive activities

These activities comprised oral production done from texts or videos and carried out with digital tools in the Moodle platform.

During the course, subjects actively engaged in speeches as members of the e-class using their linguistic competence and performance. Their practice helps them not only to reinforce grammatical structures in context and put them in their long-term memory but also to learn new vocabulary, phrases, and idiomatic expressions.

Another vital aspect that will contribute to teachers' practices citing Kelchtermans (2009) was that during the course and thanks to the type of activities, the facilitator could identify subjects' limited language and implement extra-activities to correct them.

In the case of the synchronic sessions, preparing students by getting background information for the topic to be discussed from their e-classmates was an ad hoc activity and stage (rank ideas and brainstorming activities). Then, roles-plays and songs, as well as immersive activities, fostered students' production in artificial similar real-world, which motivated them to speak naturally and spontaneously without fear of committing grammatical mistakes or mispronunciation.
The activities to closure the synchronous stage allowed learners to reflect about their content in terms of what they learn, how to join or relate the new information with their previous one, learn about cultural features and identify eclassmates interest and likes, which develop a sense of academic community to work on research activities or projects apart from this course.

Using applications, digital tools, and social networking sites lets teachers spread the learning process beyond traditional classrooms (Flores-González, et al., 2019).

In the case of asynchronous activities, the use of applications and digital tools did motivate them to speak and participate by expressing their points of view so that their e-classmates provided feedback to their answers through forums or recordings.

Besides, the percentage of subjects' participation increased in this modality in comparison to traditional classrooms. Possibly, due to the freedom and flexibility of working at any place and time.

The following graphic presents the subjects' scores from the instructional design.

Subjects' scores in synchronous and asynchronous activities



Graphic 1 Subjects' scores 
As shown in the graphic, the scores demonstrate that authentic-interactive activities promoted subjects' oral production to reach a different level of command mainly based on two reasons: competencies and descriptors of B2 included in the design, and their actual proficiency level at the beginning of the course (B1 and $\mathrm{B} 1^{+}$).

During this course, they denoted a quite broad language level to accomplish clear and accurate descriptions with standard rhythm, complex grammatical structures without mistakes that causing misunderstanding or finishing the conversation. They also monitored their participation and did corrections by themselves when necessary. In general, they carried out the following:

Give detailed explanations and a string of reasoned arguments to defend their position towards a topic.

Analyze a topic according to the advantages and disadvantages it could provide.

Speculate possible causes and effects or relationships of a given topic.

- Have successful participation in formal and informal speeches by arguing, explaining, showing pros and cons, evaluating possible solutions, confirming or refuting hypothetical situations.

- $\quad$ Emit respectful comments by supporting their speech with their experience, facts, and authors.

- Use linguistic competencies and conversational strategies to keep on in a conversation.

In summary, subjects from this study should be on a B2 level or more because they could manage themselves adequately in their course, as mentioned before.

However, the conclusion above needs some corroboration. For that reason, subjects' scores were associated with their speaking scores from a standardized exam to answer the second research question of the present study.
RQ2. Is there an association between subjects' scores from the instructional design and their speaking level from a standardized exam?

\begin{tabular}{|c|c|c|}
\hline Subjects & Variable 1 & Variable 2 \\
\hline 1. & 8.8 & $\mathrm{~B} 2$ \\
\hline 2. & 8.8 & $\mathrm{~B} 2$ \\
\hline 3. & 8.9 & $\mathrm{~B} 2$ \\
\hline 4. & 8.9 & B2 \\
\hline 5. & 9 & $\mathrm{~B} 2$ \\
\hline 6. & 9 & $\mathrm{~B} 2$ \\
\hline 7. & 9 & B2 \\
\hline 8. & 9 & B2 \\
\hline 9. & 9.1 & B2 \\
\hline 10. & 9.2 & B2 \\
\hline 11. & 9.2 & $\mathrm{~B} 2$ \\
\hline 12. & 9.3 & $\mathrm{~B} 2^{+}$ \\
\hline 13. & 9.3 & $\mathrm{~B} 2^{+}$ \\
\hline 14. & 9.4 & $\mathrm{~B} 2^{+}$ \\
\hline 15. & 9.4 & $\mathrm{~B} 2^{+}$ \\
\hline 16. & 9.6 & $\mathrm{~B} 2^{+}$ \\
\hline 17. & 9.8 & $\mathrm{~B} 2^{+}$ \\
\hline 18. & 9.8 & $\mathrm{~B} 2^{+}$ \\
\hline 19. & 9.9 & $\mathrm{~B}^{+}$ \\
\hline 20. & 10 & $\mathrm{~B} 2^{+}$ \\
\hline
\end{tabular}

Table 5 Association of the subjects' scores from the instructional design with the standardized exam

Based on the findings above, there is an association between the scores from the instructional course and subjects' proficiency level; it is evident. Indeed, the students who got a higher grade in their virtual classes did the same in their proficiency exam.

Thus, the study confirms both research questions and concludes that the proposal consisting of using authentic-interactive activities to foster oral production guides to reach a higher level.

\section{Conclusions}

First of all, the findings show a clear improvement of subjects' speaking proficiency level, and thus, linguistic knowledge.

It also provides information for teachers to improve their pedagogical practice in virtual environments to work with oral production or even to adopt this methodology and proposal to foster other skills or sub-skill. 
Besides, the use of authentic-interactive activities proved an alternative to develop oral production, which constitutes a high possibility of teaching in these times when education has migrated to virtual modalities.

By using those said activities, subjects improved their speaking proficiency level, showing acceptable parameters of interaction and performance not only in the instructional course but also in a standardized exam.

Furthermore, subjects develop a sense of virtual community where the average participation was high and characterized by their motivation to speak more naturally and spontaneously as well as learn from others not only content but also culture and social rules to interact without that typical fear and lack of motivation that is common in traditional classrooms.

The demands and requirements from the authentic-interactive activities pushed learners to be engaged in speeches with enough information to discuss and keep their rhythm in clear, accurate, and meaningful turn-takings.

Another key feature is that subjects did not demonstrate being under pressure or stressed to perform oral productions, which is an essential factor for the teaching-learning process.

Finally, it is worth mentioning that one possibility to enrich this research is by analyzing it qualitatively to have a broader scope on perceptions towards the instructional course, and in that way, taking some decisions regarding its design, re-designed, implementation, and evaluation.

\section{References}

Bialystok, E. (1990). Communication strategies: a psychological analysis of second-language use. Oxford: Blackwell.

Bransford, J.D., Vye, N., Kinzer, C., \& Risko, V. (1990). Teaching thinking and cognitive instruction (pp. 381-413). Hillsdale, NJ: Lawrence Erlbaum Associates.

Bygate, M. (1987). Speaking. New York: Oxford University Press.
Chamot, A. U. (2004). Issues in Language Learning Strategy Research and Teaching. Electronic Journal of Foreign Language Teaching, 1 (1), 14-26.

Chamot, A. U., Barnhardt, S., El- Dinary, P. B., \& Robbins, J. (1999). The Learning Strategies Handbook. White Plains New York: AddisonWesley Longman.

Cohen, A. D. (1998). Strategies in learning and using a second language. London; New York: Longman.

Creswell, J. W. (2005). Educational research: Planning, conducting, and evaluating quantitative and qualitative research (2a. ed.). Upper Saddle River, NJ, EE. UU.: Prentice-Hall. Csikszentmihalyi, M. (2013). Creativity: The psychology of discovery and invention. New York, NY: Harper Perennial.

Felix, U. (2001). The web's potential for language learning: The student's perspective. ReCALL, 13(1), 47-58.

Flores-González, E.; Fernández-Crispín, A. (2019). Estrategias de aprendizaje mediadas por tecnología para el aprendizaje significativo en la asignatura de Biología. Revista de Tecnología y Educación. $3 \quad(10), \quad 18-28$. Doi 10.35429/JTAE.2019.10.3.18.28

Flores-González, E.; Flores-González, N.; Fernández-Crispín, A. (2018). Aplicación de la estrategia mapas conceptuales para el desarrollo de la competencia comprensión lectora en Biología. Revista Teoría Educativa. 2 (3) , 2029 .

Flores-González, N. (2019). Promoting extensive reading in a blended learning modality: Students' perceptions. Journal of Teaching and Educational Research. 5 (16) , 4354. Doi 10.35429/JTER.2019.16.5.43.54

Flores-González, N., Castelan-Flores, V.; Zamora-Hernández, M.; Flores-González, E. (2019). Facebook as a tool to learn English vocabulary. Journal of Teaching and Educational Research. Doi: 10.35429/JTER.2019.16.5.10.19 
González, M. (2008). English Teachers' Beliefs about Communicative Competence and their Relationship with their Classroom Practices. ICFES \& Universidad Nacional de Colombia. Bogotá, Colombia. (p. 73-89). Recovered from: htpp://www.scielo.org.co/scielo.php?script=sci _arttext\&pid=S1657-07902008000200005

Gordon, R. (1998). Balancing real-world problems with real-world results. Phi Delta Kappan, 79, 390-393.

Green, J. M., \& Oxford, R. (1995). A closer look at learning strategies, L2 proficiency, and gender. TESOL Quarterly, 29 (2), 261-297.

Grenfell, M., \& Harris, V. (1999). Modern languages and learning strategies: In theory and practice. London; Routledge.

Herrington, J., \& Herrington, A. (1998). Authentic assessment and multimedia: How university students respond to a model of authentic assessment. Higher Education Research and Development, 17 (3), 305-322.

Kelchtermans, G. (2009). Who I am in how I teach is the message: Self-understanding, vulnerability, and reflection. Teachers and Teaching: Theory and Practice, 15(2), 257-272.

Lebow, D., Wager, W.W. (1994). Authentic activity as a model for appropriate learning activity: Implications for emerging instructional technologies. Canadian Journal of Educational Communication, 23(3), 231-144.

Leedy, P. D.; Ormrod, J. W. (2013). Practical Research: Planning and Design, (10ma. ed.). USA: Pearson.

Macaro, E. (2006). Strategies for language learning and for language use: Revising the theoretical framework. Modern Language Journal, 90 (3), 320-337.

Mendez, V. (2017). Promoting EFL Elementary Students' Speaking Skills through the use of Storytelling. Universidad Veracruzana. Recovered from: https://cdigital.uv.mx/bitstream/handle/1234567 89/48356/MendezJimenezVeronica.pdf?sequen $\mathrm{ce}=1 \&$ isAllowed $=\mathrm{y}$
Moss, D., \& Ross-Feldman, L. (2003). Secondlanguage acquisition in adults: From research to practice. Retrieved October 14, 2020 from https://www.cal.org/caela/esl_resources/digests/ sla.html

Poulisse, N. (1993). A theoretical account of lexical communication strategies. In $r$. Schreuder \& B. Weltens (Eds.), The bilingual lexicon (pp. 157-190). Amsterdam: John Benjamins.

Sagarra, N., \& Zapata, G. C. (2008). Blending classroom instruction with online homework: A study of student perceptions of computerassisted L2 learning. ReCALL, 20(2), 208-224.

Saville-Troike, M. (2012). Introducing Second Language Acquisition. Recovered from https://repository.bbg.ac.id/bitstream/588/1/Intr oducing_Second_Language_Acquisition_.pdf

Sternberg, R.J., Wagner, R.K., \&Okagaki, L. (1993). Practical intelligence: The nature and role of tacit knowledge in work and at school. In J. M. Puckett\& H.W. Reese (Eds.), Mechanisms of everyday cognition (pp. 205-227). Hillsdale, NJ: Lawrence Erlbaum Associates.

Takeuchi, O. (1993). Language learning strategies and their relationship to achievement in English as a foreign language. Language Laboratory, 30, 17-34.

Tarone, E. (1977). Conscious communication strategies in interlanguage: A progress report. In H. D. Brown, C. A. Yorio, \& R.C. Crymes (Eds.), On TESOL '77 (pp. 194-203). Washington, DC: TESOL.

Tragant, E., \& Victori, M. (2006). Reported strategy use and age. In C. Munoz (Ed.), Age and the rate of foreign language learning. Clevedon: Multilingual Matters.

Ushida, E. (2005). The role of students' attitudes and motivation in second language learning in online language courses. CALICO Journal, 23(1), 49-78.

Vann R. J., \& Abraham, R. G. (1990). Strategies of unsuccessful language learners, TESOL Quarterly, 24(2), 177-198. 
Wang, Y., \& Wang, C. (2010). Exploring EFL Taiwanese university students' perceptions of a collaborative CALL environment. Lecture Notes in Artificial Intelligence, 6241, 421-432.

Weinstein, C. E., Husman, J., \& Dierking, D. R. (2000). Interventions with a focus on learning strategies. In M. Boekaerts, P. R. Pintrich \& M. Zeidner (Eds.), Handbook of self-regulation (pp. 727-747). San Diego: Academic Press.

Young, M. F., \& McNeese, M. (1993). A situated cognition approach to problem solving with implications for computer-based learning and assessment. In G. Salvendy \& M. J. Smith (Eds.), Human-computer interaction: Software and hardware interfaces. New York: Elsevier Science Publishers.

Yule, G., \& Tarone, E. (1990). Eliciting the performance of strategic competence. In R. C. Scarcella, E. S. Andersen, \& S. D. Krashen (Eds.), Developing communicative competence in a second language (pp. 179-194). New York, NY: Newbury House. 